\title{
A Representative and a Scapegoat: Analysis of Tessie Hutchinson in The Lottery
}

\author{
Fuyu Chen \\ College of Foreign Languages, Chongqing Jiaotong University, Chongqing, 400074, China \\ Email: eric97073@yahoo.com.cn
}

\begin{abstract}
The study is an analysis of the character Tessie Hutchinson in American writer Shirley Jackson's short story The Lottery. The duality in Tessie's character represents the psychological conditions of all the participants in the lottery; while at the same time, having unfortunately won the lottery, Mrs. Hutchingson serves in the story as a victim, a scapegoat of the brutal primitive ceremony. In Tessie Hutchinson, the primitive nature of selfish and indifferent human beings is vividly revealed, which in term deserves much reflection even up to these days.
\end{abstract}

Indexed Terms - Tessie Hutchinson, The Lottery, representative, scapegoat, character

\section{INTRODUCTION}

The Lottery is the most important piece of work by Shirley Jackson, first published in June 26, 1948. Written in the same month it was published, it is ranked today as one of the most famous short stories in the history of American literature. Of all the characters shaped in the story, Tessie Hutchinson is without doubt the central figure, in whom blends the roles of a representative and a scapegoat.

On the morning of June $27^{\text {th }}$, quietly and smoothly, going on in a small American village is a traditional ceremony, a sacrifice ritual for the God of vegetation. Within two hours' time, from ten o'clock to noon, the whole matter undergoes all its procedures and ends with a stoning upon Tessie Hutchinson, which then allows "the villagers to get home for noon dinner"(Jackson, 1982, p.291). Such is the plot of The Lottery. The everyday-like tone by the author in a third-person narration has brought to the reader an unexpected development and chilly ending in such a short composition.

To a big proportion of its readers worldwide, the story is not in the least unfamiliar, for similar cases are too be found in different parts of the earth, from America to Asia and Africa, particlularly in remote places in a certain period of human history. Hints of simliar ceremonies can still be found in books, legends, folksongs, or other records either in oral or written forms. What distinguishes Jackson's story is the chillingly unexpected ending, where exaggerated or not a woman was stoned to death as a sacrifice for the unknown and intangible spirit, and more importantly, the revelation of the ugly human nature, which was once common but hard to accept in modern societies.

By far the real theme of this short story remains a mystery and a controversy to many contemporary critics, yet we can at least draw some basic traits from the event proper. Beyond doubt, some more profound aspects await to be explored. Through the narration of the ordinary, everyday-like way in which The Lottery takes place and the descriptions of the friendly, neighborly behaviors and later indifferent attitudes of the townspeople, Shirley Jackson exposes one of the darkest dualities of the human nature, "the awful doubleness of the human spirit - a doubleness that expresses itself in the blended good neighborliness and cruelty of the community's action."(Gunton, 1979, p.225) This duality is embodied in many of the characters in the story; however, Tessie Hutchinson is the most typical, in whom we can notice a nature of double sides - enthusiasm in participation and unwillingness in accepting the role of the victim, and the duality mentioned previously. Therefore, she is the best representative for the villagers, especially women, and at the same time she plays a scapegoat in the story.

\section{TesSie HutChINSON—A REPRESENTATIVE}

A representative is a "person chosen or appointed to represent another or others"(Hornby, 1997, p.1272) or "a person who has been chosen to speak, vote, or make decisions for someone else." (Longman, 1997, p.1202) For example, Members of Parliament (MP) are usually chosen by the public to be on their behalf - to speak for the voters, to make important decisions, to choose the right way of the social and economic development of the country. The representatives thus must always bear in mind the interest of their supporters. The meaning of a representative is best seen in Head of the State like President of the US. He or she is elected from among the several candidates, who may represent the interest of different social classes or groups. When the voters have to choose one from among many, a comprise has to be made, which means their own interest is represented by the elected more or less.

As is clearly seen, Tessie Hutchinson is chosen, in the story of The Lottery, by the townspeople, as well as by herself, surely also by Shirley Jackson, as the representative for the others. 
From the appearance of the townspeople before the ceremony, children first, then men, and finally women, the reader can sense the neighborly and daily atmosphere in which the sacrifice is going to take place - actually it is hard enough to have any idea of what there is going to be at the beginning. Bear in mind how Shirley Jackson describes the emergences of the three types of people.

Children: "...before they broke into hoisterous play, and their talk was still of the classroom and the teacher, of books and reprimands..."

Men: "...soon the men..., speaking of planting and rain, tractors and taxes..."

Women: "wearing faded house dresses and sweaters..."(Jackson, 1982, pp.291-2)

All the above descriptions implicate that the town folks have long got used to the event and have taken for granted the sacrifice of a friend's or a neighbor's life. It is so natural and they are so carefree as if they are there for fun. In short, in the first three paragraphs of the story, Shirley Jackson reveals the general attitude of the villagers towards such a primitive ceremony.

\section{A. Emergence of Tessie Hutchinson}

Then, after a period of foreplays of the villagerss - information exchanges and some preparations for the ritual, here shows up our heroine, Mrs. Hutchinson-"Mrs. Hutchinson came hurriedly along the path to the square, her sweater thrown over her shoulders, and slide into place in the back of the crowd." (Jackson, 1982, p.294)

It is obvious that her appearance is somehow different from the others'. While all the other villagers have already gathered on the square, she is the only person (not considering the leg-broken Clyde Dunbar who certainly will not appear into the happening at all.) to be late for the ceremony. This shows that her casualty or callous indifference to the matter is of a much higher degree than those of the others. Like a student late for class, it is seen for the first time, Tessie Hutchinson probably regards the ceremony as routine and has got used to it, and it is no longer of much importance in her.

Tessie Hutchinson even forgets the coming of this June $27^{\text {th }}$, such an important day in the eyes of the readers on which is the ceremony_ “"clean forget what day it was'... and they both laughed softly". (Jackson, 1982, p.294) How could people in this village forget such an important ("important" only in the reader's eyes) date? The only reason is that (in Tessie's mind - actually in most of the villagers' mind) it is no longer of any special importance. It is something trivial instead. However, she is afraid of missing such an enjoyment - she "“...came a-running"”, "craned her neck to see..." "...dried her hands on her apron", "she tapped Mrs. Delacroix on the arm as a farewell (a death farewell)..." (Jackson, 1982, p.294) and later she said (to Mr. Summers), grinning, "Wouldn't have me leave m'dishes in the sink, now, would you, Joe?" (Jackson, 1982, p.295)

All the descriptions vividly illustrate the frisky, in-a-hurry appearance of Tessie Hutchinson, whose behavior is so typical among the folks that she may be considered the representative for the whole townspeople. Note how essentially similar are the appearances of the other villagers, especially those women, compared with the outstandingly typical Tessie Hutchinson.

\section{B. Tessie Hutchinson during the Lottery}

The lottery in Shirley Jackson's story traditionally undergoes two phases of slip-selection. The first round is drawn by the heads of the families hosted by some big figure in the town, in which a representative of each family is arranged to select a paper slip from the weathered wood box, which will determine the family winning the lottery. The second round is exercised within that "lucky family", when each member selects a slip and the only final winner is revealed.

\section{First round - fate of the family as a whole}

At this moment, the heads of families are required to draw a paper each on behalf of the whole family. When the name Hutchinson is called by Mr. Summers the chairperson, “'Get up there, Bill,' Mrs. Hutchinson said, and the people near her laughed." (Jackson, 1982, p.297)Although Tessie seems somewhat funny, she is still a representative for all those women - their behaviors are of no essential difference. For example, the behavior of the other two women:

a. Mrs. Delacroix - “"There goes my old man,' Mrs. Delaxoix said. She held her breath while her husband went forward." (Jackson, 1982, p.297)

b. Mrs. Graves_-“"We are next,' Mrs. Graves said...” (Jackson, 1982, p.297)

Though there are some subtle differences in their words and behaviors, their anxieties and agitations are of the same essence as those of Tessie Hutchinson's. There might be some minor differences in the details of the women's acts, but there is definitely one thing in common, and that is their casualty and fun-seeking attitude during the ceremony. Surely there are more women or even men of the same or similar cases.

It seems difficult to compare Mrs. Hutchinson with the others as the result of the first round has already come out, for they are then in the opposite positions. In another sense, however, we may make a vertical comparison between them. “...when all the slips of paper were opened. Suddenly, all the women began to speak at once, 'Who is it?' 'Who's got it?' 'Is it the Dunbars?'... 'Bill Hutchinson's got it." (Jackson, 1982, p.298)Understandably, Tessie makes no words now, for her family has been too "lucky" not to win the lottery, which separates her from the other women instantly then. But we can imagine Tessie's performances in the previous years, when it was not the Hutchinson that "won" the lottery. It is likely that the following words uttered by Tessie Hutchinson (Jackson, 1982, p.298), "You didn't give him time enough to take any paper he wanted. I saw you. It wasn't fair", were similar to, if not the same as those words by the 
victims in the past years. While the two sentences (Jackson, 1982, p.298), "Be a good sport" by Mrs. Delacroix, and "All of us took the same chance" by Mrs. Graves, could possibly be spoken out by Tessie Hutchinson in the past years. So in this sense, Tessie Hutchinson continues to be the representative of the villagers.

\section{Second round-inside-family lottery}

In the second stage of the lottery, it seems even more difficult to compare Mrs. Hutchinson with the other townspeople, even with the other members of the Hutchinson family. Yet it is of great importance to. Bear in mind that a representative should at least have something in common with the group of people s/he is to represent. When Mr. Summers asks Bill, "You got any other households in the Hutchinsons?" "“There's Don and Eva,' Mrs Hutchinson yelled. 'Make them take their chance."' (Jackson, 1982, p.299) In these two short sentences, we unwillingly find the diminishment of the motherhood and humanity.

"Tessie reacts like a frightened animal; but, unlike the animal mother, the human mother does not always seek protections for her offspring. In fact, instead of giving her life for her children, Tessie prefers that they take their chances also - and she tries to have her (married) daughter Eva (and Don)...include in the fatal drawing to increase her own chances for survival." (Gunton, 1979, p.231)

This chillingly evil nature as a mother astonishes the reader. However, Tessie's intimates, the other members of the family, are no better. Once they find that they are not the chosen sacrifice, they feel relieved and laughes, not at all concerned about their mother's or wife's immediate death. As it was stated by Cleanth Brooks and Robert Penn Warren, "...More over, even the individual members of the Hutchinson family are themselves relatively unconcerned once each discovers that he is not the victim chosen." (Gunton, 1979, p.225)

For this reason, “...Nancy and Bill, .Jr. opened theirs at the same time, and both beamed and laughed, turning around to the crowd..." While later "...Bill Hutchinson went over to his wife and forced the slip of paper out of hen hand..."(Jackson, 1982, p.299) In the sense of the indifference to the family relationship, Tessie Hutchinson represents the whole family, for the non-concerned attitude of the other members actually has the same nature as Tessie's loss of motherhood.

Further more, in a broader sense, Mrs. Hutchinson remains a representative for the villagers as a whole, for their behaviors are essentially comparable to, and of the same evil root as, that of Tessie Hutchinson. "A further point is this: human beings find it difficult to become exercised over ills not their own. Once a family group sees that the victim is not to be selected from among themselves, they proceed to observe matters with a certain callous disinterest." (Gunton, 1979, p.225)

\section{Tessie Hutchinson after Result Discovered}

As has been briefly discussed at the beginning, the duality in Tessie Hutchinson's character is of typical nature. Her behaviors during the whole event serve as a strong evidence to the double-sidedness inside herself. She is enthusiastic to take part in the lottery at first - she is then the representative for most of the villagers, if not all, who are probably more agitated than Tessie, as all of them come to the suqare earlier than Tessie Hutchinson. How does she change as the ceremony goes on? We readers all know that she protests the "unfair" (but open indeed) slip-drawing procedures, and even that her protest changes gradually with the development of the lottery. When it is discovered that the Hutchinson has got the Lottery, "Tessie Hutchinson shouted to Mr. Summers, 'You didn't give him time enough to take any paper he wanted. I saw you. It wasn't fair." Then as she is told that "daughters draw with their husbands families", again, "'It wasn't fair,' Tessie said." (Jackson, 1982, pp.298-9)

Then as the inside-family lottery begins, though she is still protesting, Mrs. Hutchinson does behave as a "good" sport, "She hesitated for a minute ... went up to the box. She snatched a paper out and held it behind her." (Jackson, 1982, p.300) The only reason for her sportsmanship is that she still holds the chance or the hope to survive, for it is possible that any of the other members may "win" the lottery. And so long as she might escape to be doomed, anybody else in the family is non-of-her-business. But, the final result smashes her tiny hope. Her duality seems ridiculous to us, yet she represents the attitude of the other members of the family, surely also most of the people in the village.

"Tessie Hutchinson shows both the evils and the weakness of mankind faced with immediate death. Her hypocrisy indicates that she would willingly take part in the stoning; but, when she is the chosen sacrifice, she is not willing to be a good sport about giving up her life." (Gunton, 1979, p.231) So commented the critics. From this point of view, Tessie Hutchinson is a representative not only for her own family but also for all the villagers, even the whole mankind. The dark side of human nature becomes darker in the sunlight.

\section{TESSIE HUTCHINSON-A SCAPEGOAT}

Some literary critics hold that the theme of The Lottery is a modern representation of the scapegoat (Gunton, 1979, p.223). In the introduction to The Lottery in CLC, it is stated that "many critics observe that the story reflects humankind's ancient need for a scapegoat, a figure upon which it can project its most undesirable qualities, and which can be destroyed in a ritually absolving sacrifice." (Gunton, 1979, p.221) But the authentic theme remains a controversy for so far the author Shirley Jackson made no further interpretations to the story. However, the author of this paper holds, Tessie Hutchinson in The Lottery does really plays the role of a scapegoat. Whenever something unpleasant takes place, there must be someone to shoulder the responsibility for it. In the war, it may be a general; in a recession, it may be the 


\section{Minister of Treasury.}

\section{A. Definitions of a Scapegoat}

A scapegoat is defined as "person who is blamed or punished for the wrongdoing of somebody else" in Oxford Advanced Learners' English-Chinese Dictionary (Hornby, 1997, p.1338), or "someone who is blamed for something bad that happens even if it is not their fault" in Longman Dictionary of Contemporary English (Longman, 1997, p.1271).

In Frazer's The Golden Bough, a scapegoat is more broadly defined as:

“....an animal or human being used in public ceremonies to remove the taint or impairment consequent upon sin which, for one reason or other, cannot be saddled upon a particular individual. Such a scapegoat is a means of 'cleansing' a community of a collective stain, which cannot be wiped out by the normal procedure of individual penitence, restitution, and reform. The execution or dispatch of it is always and necessarily accomplished by a blanket public confession." (Gunton, 1979, p.231)

Further more, Frazer discusses the four aspects of scapegoats and scapegoat rituals as following.

First, the scapegoat provides a "visible and tangible vehicle for bearing away a community's invisible and intangible evils." Second, "when a general clearance of evils is resorted to periodically, the interval between the celebrations of the ceremony is commonly a year, and the time of year when the ceremony takes place usually coincides with some well-marked change of season." Third, Frazer states out "that this public and periodic expulsion of devils is commonly preceded or followed by a period of general license, during which the ordinary restraints of society are thrown aside, and all offences, short of the gravest, are allowed to pass unpunished." And finally, Frazer notes that the scapegoat victim is often believed to be divine, "the employment of a divine man (woman) or animal as a scapegoat is especially to be noted." (Frazer, 1999, pp.575-6)

Now let us make an observation into Tessie Hutchinson's conditions to approve that she does act as the scapegoat in this "holy" event, respectively according to the definitions above - the ones by the dictionaries and by Frazer.

\section{B. Tessie Hutchinson as a Scapegoat}

\section{In Accordance with Dictionary Definitions}

Obviously, the innocent Tessie Hutchinson is blamed or punished to death, not because she has done something wrong or bad. And the "wrongdoing/ something bad" that happens within the village is certainly not her fault — though we are not sure what the wrongdoing/something bad really is. Possibly this something is concerned with fertility or harvest as hinted by Old Man Warner's proverb "Lottery in June, corn be heavy soon" (Jackson, 1982, p.297), something superstitious commonly seen in remote parts of the world at the time.

\section{In Accordance with Frazer's Definition}

Firstly, there is no doubt that as a village woman Tessie Hutchinson herself is "visible and tangible" - everyone can see her coming running alive to the square. While the evils of the small village she is going to take away with her death are "invisible and intangible". Nobody in the viallge has even seen in person the evil, not even the oldest ones. Although it is no more than something legendary or imagined and passed down from generation to generation, the townspeople would rather believe in the existence of such a spirit and make sacrifice to it anually with the life of a person, man or woman, young or old.

Secondly, we have known, from the words by the villagers, especially by the Old Man Warner's "Seventy-seventh year I have been in the lottery...seventy-seventh time", (Jackson, 1982, p.298) that this sacrifice ceremony is held annually. Seventy-seven lives deminished in his lifelong participation in the ceremony! How many all together from the very start of THAT tradition? We also get ideas from Warner's "Lottery in June, corn be heavy soon" (Jackson, 1982, p.297) that the time of the lottery is the turn of season, or at least we can infer that it is "key time" for vegetation. To ensure abundance in agricultural ouptup, in th eyes of the villagers, the sacrifice of a life annually is rather worthwhile. Otherwise the ceremony would have been abandoned long long ago.

Thirdly, we here venture to interpret Frazer in short as: The ceremony in which a scapegoat appears or is chosen should be of so great a significance that the people involved must quit their daily work in order to take part in it. It so happens that in The Lottery, when the children are recently freed from school, which is only possible in public hoildays in modern time. Yet the more important fact we should notice is that the adults, male or female, young or old, all stop their working at hand and gather on the square, except the leg-broken Dunbar. All this shows how serious they are on this very occasion - it is much more important than many other important days in the place: birthdays, wedding days, funerals, and the like. And,

Finally, as the divinity of the victim/ scapegoat is concerned, it is necessary to mention the leg-broken Clyde Dunbar, who is then excluded from being chosen in the ritual. The divinity of the ceremony requires the sacrifice to be healthy so as to express the respect for the unknown spirit. Contrary to Dunbar, Tessie Hutchinson satisfies the lowest criterion of divinity - she is at least physically wholesome.

Such a blind belief in the intangible shows how primitive and stupid they are. But there are more brutal examples in legends of the world. For instance, as is said in Chinese legends, in an ancient place Ye, where there was a drought, people would send a couple of virgins - male and female, as a sacrifice for the God of River. The children were then drowned into the river to convey the piety of the local people. The innocence and purity of children were pondered as 
divine while adults were no longer qualified for sacrifice as they were dirty and their flesh untasty.

Through the discussion in the foregoing several paragraphs, Tessie Hutchinson is in the proper position of a scapegoat required by the dictionary definitions and Frazer's interpretations. Physically wholesome, she is selected by the people and, more importantly, by herself, to received a fatal punishment for the unknown "wrong doing" of the villagers, which is targeted at the better.

According to Seymour Lainhoff, the scapegoat rite generally has a double purpose: "to exorcise the evils of the old year by transferring them to some inanimate or animate objects, and ...to insure fertility."(Gunton, 1979, p.223) Based upon his purpose-oriented interpretation, the lottery in the story is, beyond doubt, exactly in this case. On the one hand, though we are not yet clear what the evil is (Possibly it never really exists, but the villagers hold the idea of evil merely upon their tradition or custom), it is transferred to an animate object, i.e, Tessie Hutchinson. On the other hand, we know from the Old Man Warner that the lottery is to ensure fertility. Then we come to the conclusion to this part, in the form and function, Tessie Hutchinson in The Lottery performs the victim as a scapegoat in the story.

\section{CONCLUSION}

Now a conclusion on the doubleness in Mrs. Hutchinson's character can be naturally drawn. Tessie Hutchinson is a representative of as well as a scapegoat for the townspeople, as has been discussed in the previous parts. She represents the primitive evil nature of human being in the modern society. Her tragedy at the same time is a representative of the tragedies of those people chosen as the sacrifice in the past, and will continue to be thereafter. In The Lottery, Shirley Jackson makes Tessie Hutchinson sacrifice her life, which has to a high degree been implied by her behavior from the very start, and makes her a character representing most of the villagers. As the scapegoat of this year, Tessie Hutchinson, just like those who had already sacrificed their lives before her and those who will do so after her, is also a representative. In a word, Tessie Hutchinson is a blend of a representative and a scapegoat. If Shirley Jackson would rewrite the story, it is not impossible that Tessie Hutchinson might be replaced by the name of another person, who would to a great extent inherit the identity of a scapegoat and a representative.

As similar ceremonies are to be found in different parts of the world in its history, earlier here and later there, The Lottery in itself serves as a representative of all those brutal and primitive worships to the spirits, an important memory in human history. In her own way, Shirley Jackson reminds us of the true values of the civilization and the promotion of human nature in this brief but classical story.

\section{REFERENCES}

[1] Frazer, James G. (1999). The Golden Bough. Beijing: China Social Sciences Publishing House.

[2] Friedman, Lenemaja. (1975). Shirley Jackson. Boston: Twayne Publishers.

[3] Gunton, Sharon R. (ed.) (1979). Contemporary Literary Criticism (CLC), Volume11. Farmington Hills, Michigan: Cengage Gale.

[4] Hornby, A. S. (1997). Oxford Advanced Learners' English-Chinese Dictionary. Beijing: The Commercial Press.

[5] Jackson, Shirley. (1982). The Lottery and Other Stories. New York: Farrar, Straus and Girour.

[6] Longman. (1997). Longman Dictionary of Contemporary English. Beijing: Foreign Language Teaching and Research Press.

Fuyu Chen was born in Fujian, China in 1978. He received his M.A. degree in literature from Sichuan Normal University, China in 2004.

$\mathrm{He}$ is currently a lecturer in the College of Foreign Languages, Chongqing Jiaotong University, Chongqing, China. His research interests include Language Teaching, Literary Translation and Cross-cultural Communication. 